Clyde, Laurel A

International Association of School Librarianship. Selected Papers from the ... Annual Conference; 2000;

Education Database

pg. 169

Infonnation Literacy: Key to the Future

\title{
School Libraries Online: \\ Exploring Issues and Developments Through the IASL Website
}

\author{
Laurel A. Clyde
}

Faculty of Social Science
University of Iceland
Iceland

\section{Background}

In Internet terms, the origins of the Web site of the International Association of School Librarianship are shrouded in the mists of antiquity. Way back at the beginning of 1995, I established IASL-LINK as an Internet listserv for the Association. Dr Jean Lowrie, a founder of IASL and then retiring as Executive Secretary, wanted a home page for IASL. I, too, thought we should have a home page and probably a full Web site. Others doubted that the Association had the resources to do this - or even that it should be done at all. Those of you who know Jean will know that she is persistent, and in this case she focused that persistence on me. I felt that establishing a Web site was a job for a bright young member of the Association, and so I kept hoping that "someone else" would do it. In the end, I lost patience just at the time Jean became very persistent. In November 1995 I created a home page for IASL, with eleven supporting pages, just to prove that it could be done. Thus it was that I found I was the Webmaster.

The original pages were very simple in design so that they could be viewed through any of the Web browser software that was available in schools and libraries at the time and so that they would occupy little bandwidth and come through fairly fast even for users on slow Internet connections. As browser software has improved and more IASL members have fast connections, these two considerations are not as important now as they were in the beginning, though I am still aware of them when I create new pages.

In November 1998, the Web site underwent a major redesign, at which point it was re-named "School Libraries Online." An immediate result of these changes was that usage of the site doubled in December 1998, and it has continued to grow at an increasing rate ever since.

There are now more than 360 pages of information on the system, but this does not represent the total number of pages created. Some pages, such as the one created early this year for the nomination of new IASL Board members, have a fairly short life span, while other pages, such as the one that covers the history of IASL, have been on the system since the beginning. On average, six or seven new pages are created each month.

At the moment, the Web site is based on a mainframe computer at the University of Iceland. By the end of the year, however, it will have been moved to a computer in Vancouver, Canada, where our new domain name is registered and where it is close to the IASL office. 


\section{Online Demonstration}

The "School Libraries Online" home page serves as the main point of access to the resources and services available through the Web site, and reflects the general structure of the site. There are two main components of the "School Libraries Online" home page. One is the "Site Directory" that leads users to information created by the Association. The other is a collection of icons surrounding the directory that leads users to information resources and services of various kinds on the Internet and to some special services on "School Libraries Online" itself. While the site directory remains relatively stable as an overall guide to the site, the icons change frequently, since they highlight resources and activities that change throughout the year.

\section{The Site Directory}

- "About the Association" (with objectives, activities, office-bearers and directors, history of the Association, the IASL Handbook of Organization and related documents, annual reports, and the Association's Policy Statement on School Libraries)

- The IASL Newsletter (with the full text of selected articles from the print newsletter 1995-2000)

- School Libraries Worldwide, the IASL professional/research journal (with contents lists and abstracts of articles provided by the Editor of the print journal, Dr. Dianne Oberg of Canada)

- Professional Reviews (coordinated by the IASL Review Coordinator Peter Genco of the United States)

- The Annual Conferences (with information about forthcoming conferences, reports of past conferences, and the contents pages of the volumes of conference proceedings and/or selected papers)

- Committees and Special Interest Groups of the Association (I wish I could say more about this!)

- The IASL Noticeboard (with current deadlines, information about conferences, and other activities)

- IASL-LINK: The Association's Listserv (with information about subscribing and participating)

- IASL Publications (with a list of publications and ordering information)

- The IASL International Awards Programme (with information about previous winners and application information)

- "How to Join the Association" (with application form) 
- School Librarianship Documents (with links to the full text of documents such as policy statements, articles, conference papers, and bibliographies)

- Links to School Library Resources on the Internet (with more than 20 pages of annotated links to evaluated resources in categories such as "educational resources," "information skills resources," "school library automation resources," "resources for reading promotion," and "resources for professional development")

Other Resources and Services

In July 2000 , the resources and services available through the icons on the home page included the following:

- "Current News" related to school libraries (the full text of articles, provided through a search of more than 300 current news sources and services)

- "Today is..." (a collection of Web-based services to support school library displays and activities, including "Today in History" and "On This Day")

- "Did You Know?" (a "daily factoid" and collection of evaluated links to curriculum-related Web sites dealing with a topic of the week, from Barbara J. Feldman, author of the syndicated column "Surfing the Net With Kids")

- International Year for the Culture of Peace 2000 (a page of links to selected Internet resources for this special year)

- Resources related to the Sydney 2000 Olympic Games (provided by the Victorian Department of Education)

- International School Library Day (IASL's Web pages to support International School Library Day, plus International School Library Day projects)

- The IASL/Concord School Library Web Page Award (the pages through which this monthly and annual award is administered)

Search services available through the home page include a site search engine, an option for searching Encyclopaedia Britannica online, a link to the Blue Web'n searchable database of educational resources on the Internet, and a link to the Yahoo! search engine and directories.

\section{Foundations}

Different ideas, documents, theories, and discussions have informed the development of the IASL Web site at different stages. When work commenced in 1995, the relevant professional and research literature was sparse. In this situation, the best approach seemed to be to work from the emerging technical standards (to ensure that the Web site would be accessible from a range of different computers running different browser software) and to use a strategic planning process that emphasized objectives and meeting user needs. These considerations continue to drive Web site development. However, as the professional and research literature has matured over the five years, "School Libraries 
Online" has incorporated ideas from professional practice, findings, and theories from research as well as the results of ongoing monitoring and evaluation of the Web site itself.

The mission statement and objectives of the Association provided a foundation for the early work on the Web site: "The mission of the International Association of School Librarianship is to provide an international forum for people interested in promoting effective school library media programs as viable instruments in the educational process." The mission statement also describes the members of the Association:

\begin{abstract}
Membership is worldwide and includes school librarians, teachers, librarians, library advisers, consultants, educational administrators, and others who are responsible for library and information services in schools. The membership also includes professors and instructors in universities and colleges where there are programs for school librarians, and students who are undertaking such programs.
\end{abstract}

These various different groups of members all have information needs, some of which are common to all or most of the groups and some of which are unique to a particular group.

The objectives of IASL state that, amongst other things, the Association will promote the development of school libraries throughout all countries, foster a sense of community among school librarians in all parts of the world, promote the professional development of school librarians, encourage research in the field of school librarianship, promote the adoption of research results in practice, disseminate information about programs and materials, and initiate and coordinate activities such as conferences and projects. Thus the Association's work is international and based on communication, creation and dissemination of information, and coordination of activities and projects to meet the needs of a diverse membership that nevertheless focuses on many common interests and concerns. purposes:

In keeping with this, the Web site was initially designed to serve three main

- to provide information about the Association and its activities for members and non-members

- to provide information and services for school library personnel, including information about projects and activities, professional development opportunities, current developments in the field of school librarianship, articles and papers, research reports, news, and opportunities to participate in Web-based activities; and

- to help school library personnel to explore the Internet, and particularly to help them to find resources and services that are relevant to library and information services in schools.

To these, a fourth purpose was subsequently added:

- to provide a basis for the management and/or operation of Association projects.

This last reflects two different trends during the five years: the increasing level of access to the Internet, even in developing countries, so that more IASL members can take part in 
Internet-based projects; and the increasing availability of software that assists the operation of such projects.

Initially, the Web site had a very simple structure of menus leading to information created by the Association and to collections of links to Internet resources in the field of school librarianship. Over the last two years, however, "School Libraries Online" has been developed further with the aim of creating a fully-fledged "portal" or "subject gateway" to the Internet for school library personnel, which is in line with the ideas of Koch (2000) and Dempsey (2000) as implemented in the Electronic Libraries Programme (eLib) in the United Kingdom. In addition to original content created by the Association, the Web site provides a subject gateway to "support systematic resource discovery," quality-controlled and classified links to resources (documents, objects, sites or services), and value-added features.

Over the five years, work on the Web site has been influenced by books such as Roger Black and Sean Elder's Web Sites That Work (1997), David Siegel's Secrets of Successful Web Sites (1997), and Molly Holzschlag's Web by Design (1998). Louis Rosenfeld and Peter Morville's ground-breaking book, Information Architecture for the World Wide Web (1998), was as important for me as it was for many other Webmasters. Research that has provided useful insights includes the work of Virginia Cano and her colleagues on municipal Web sites in the United Kingdom (Cano \& Prentice, 1998), a national study of school Web sites in the United States of America, Helge Clausen's work on academic library Web sites in Denmark (Clausen, 1999), and my own international studies of public and school library Web sites (Clyde, 1996; Clyde, 1999).

\section{Keeping Up}

Various sections of "School Libraries Online" are designed to provide current information related to issues and developments in school librarianship and/or to provide links to Internet resources that will help school library personnel to keep up to date. Among these are the "Current News" button on the home page, the reviews section (which reviews professional materials for school library personnel), and the section of links to school library resources on the Internet.

\section{Current News}

The "Current News" button leads to a service that is offered in conjunction with the Internet search engine Excite. When users click on this button, the search engine initiates a search of more than 300 news services internationally for current stories related to school libraries. News sources covered include newspapers from the United States, Canada, Australia, Norway, and other countries; magazines such as $P C$ World; and news services like PR Newswire, CNET, and Business Wire. An additional "photo search" and/or an additional "audio/video search" can be carried out from the bottom of the search results page. Topics covered by the "Current News" service include, among others, policy and legislation, funding, censorship, use of technology, personnel issues, and school and public library cooperation. The results of the search are presented as a day-by-day listing going back one week, with the possibility to go back a further week. Users can see the full text of all articles retrieved by the search engine. This service is useful for those who require up-to-date information on developments such as challenges to school library materials, or for those who are tracking a particular issue through the news media over a period of time. 


\section{The Reviews Section}

The "Reviews" section of "School Libraries Online" is the result of an international collaboration. Peter Genco, IASL's Reviews Coordinator, is a school library media specialist and technology team leader at a secondary school in Erie, Pennsylvania, USA. Peter takes delivery of new professional publications (books, software, CD-ROMs) from publishers in several countries. He assigns the materials to reviewers worldwide, collects and edits the reviews, and then sends them to the Webmaster by email. He also provides notes about any links that should be made (for example, to the Web site of the publisher or author). The reviews are then added to the Web site, using a page template to speed up the process and to ensure that all review pages are in the same format. The review indexes are updated as each new review is added.

Each review has a "hot link" to the Amazon.Com Web site, so that users of "School Libraries Online" can go direct to Amazon to purchase a copy of the book or resource. Users of the IASL Web site also have access to the reviews on the Amazon Web site, so that they may have more than one opinion about any book. IASL is an Associate of Amazon, which pays the Association a small fee for every book that is purchased as a result of a link from the "School Libraries Online" Web site. The Association will use this money to support a member in a developing country, something that is particularly important in terms of the Association's objective to promote the development of school library services throughout the world.

\section{Links to School Library Resources on the Internet}

The section of "Links to School Library Resources on the Internet" is one of the most frequently-accessed sections of "School Libraries Online"; it is also the most timeconsuming to maintain. This section provides annotated links to hundreds of Internet sites of interest to people who are involved in school librarianship. In keeping with the aim of helping school library personnel to explore the resources that are available on the Internet, this section provides links to the best resources available.

The listings are selective rather than comprehensive, and resources are evaluated before links are made. Selection criteria include relevance of the resource to the work or professional concerns of school librarians, currency, timeliness, authority, organization of the resource, and coverage. Many of the resources have been chosen because they lead to further lists of resources (index sites or directories or "meta-sites"); some of them are general; and some of them relate to particular aspects of librarianship, school librarianship, or education. The exceptions to the latter include the Web sites of professional associations in the field of school librarianship, sites with information about a particular school library automation system or information skills resource, and sites that contain useful information for school librarians that is not available elsewhere.

In addition, there are links to some lists of resources that have been created especially for IASL, for instance, IASL's own collection of documents related to school librarianship around the world. There are more than 20 pages in this section, organized under the following headings:

- Library Associations

- School Library Associations

- School Libraries and School Librarians on the Internet 
- Resources for School Librarians

- Educational Resources

- Information Skills Resources

- School Library Automation Resources

- Children's Literature Resources

- Internet Resources for Reading Promotion

- Internet Resources for Storytelling

- Research in School Librarianship - Resources

- Resources for Professional Development

- Internet Resources for Kids

- Other Useful Resources

- School Librarianship Documents

- Electronic Journals Related to School Librarianship

- Creating a Web Page for Your School Library - Resources

Some of the pages in this section contain important collections of links. For example, the page for "School Library Associations," organized by country, has links to all school library associations that are known to have a Web site, while the page of links to "School Library Automation Resources" has an alphabetical listing of links to the Web sites of vendors/developers of school library automation systems.

\section{School Library Websites}

There are two international directories of school library Web sites, one maintained by Linda Bertland and one by Peter Milbury (both in the United States); both show that the number of such sites is increasing. One of the early pages on the IASL Web site highlighted the Web pages of Association members. One of my personal hopes for "School Libraries Online" was that it would be a catalyst for the development of school library Web pages, that it would encourage IASL members to become actively involved in building the Internet. With this in mind, I proposed to the IASL Board that a new award be approved for a school library Web page and found an enthusiastic sponsor in a fellow Australian whose company creates and markets school library automation software that includes a Web interface.

In late 1999, the Association established the IASL/Concord School Library Web Page Award with sponsorship from Concord Australia. The aim of the award is to promote the involvement of school librarians in the development of the Web and to promote excellence in school library Web sites by highlighting "best practice." This award is made to a school library Web page, from any country, that meets the selection criteria. Web pages may be nominated by any IASL member or by any member of the Selection Committee. In addition, members of the Selection Committee actively seek out potential award-winning Web pages. Both the award itself and the activities of the Selection Committee are coordinated through the IASL Web site and by email. The selection criteria are available through the Web site, and there are links to the Web sites of previous winners of the award.

The IASL/Concord School Library Web Page of the Year Award takes the form of a cash grant, a plaque for the winning school library, and the award logo that the school library can download to its Web site to show that it was the winner of the IASL/Concord School Library Web Page Award for that year. A School Library Web 
Page of the Month is announced each month, and the annual winner is selected from among these 10 to 12 school library Web pages before the IASL conference each year. The winners of the monthly awards are able to download an award logo for their Web site to highlight their achievement. All the School Library Web Page of the Month Award winners are reviewed again by the Selection Committee before the conference to make sure that they are still in existence and still of an appropriate standard as well as to assess any changes. The winner of the IASL/Concord School Library Web Page of the Year Award is announced at the annual conference.

\section{International Activities}

In the last two years, more and more members of IASL have gained access to the Internet. At the same time, some Internet costs have decreased while both browser software for users and page creation software for page developers have become more sophisticated. This has meant that it has been possible to extend the applications of the Association's Web site beyond the primary applications of information dissemination and communication. In particular, we have been able to develop the Web site as the basis for some of the Association's projects and activities. Two important examples from $1999 / 2000$ are the use of "School Libraries Online" as the basis for activities for International School Library Day and the coordination of the IASL/Concord School Library Web Page Award through the Web site. The latter has already been mentioned; the former will be discussed here.

Early in 1999, the IASL President, Dr. Blanche Woolls, formally proclaimed that International School Library Day would be held on the third Monday of October each year. The first International School Library Day was celebrated on 18 October 1999, with the theme "A day in the life...". The day focused on the many activities and issues that make up the daily life of school library personnel around the world. The first

International School Library Day was organized in conjunction with a special issue of the IASL journal, School Libraries Worldwide, edited by Dr. Dianne Oberg. The IASL Web site was used to present stories, anecdotes, photographs, and other material submitted "on the day" by people involved in school librarianship. Members of the Association and others were invited to read the stories of their colleagues and to submit their own stories in words and pictures. The stories could be short or long; they could comment on the submissions of others; but the aim was to collect reflections on school libraries from some of the variety of people who work at many levels for the provision of school library programmes and services. Stories and other material could be submitted by email or via a special Web page on the site.

In all, more than 30 people submitted stories, photographs, and URLs during the day; all appeared on the "School Libraries Online" Web site. They included submissions from South Africa, Australia, Canada, New Zealand, the United States, Scotland, Russia, the Republic of the Seychelles. Malta, and Namibia. The Queenslanders contributed a series of photographs of "a night in the life..." of teacher librarians celebrating at a professional function. The special issue of School Libraries Worldwide (which also had the theme "A day in the life...") appeared in January 2000. It included not only stories written specially for the journal by people who are active in school librarianship in different countries but also a section that drew together the stories from the Web site (Oberg, 2000). This means that although much of the International School Library Day activity took place on the Web site, there is also a formal printed record of the contributions. The October 2000 celebration of International School Library Day will also be based on the Web site with other activities, too. 
It is my hope that we will be able to use "School Libraries Online" as the basis for more Association activities in the future, and I will be talking to various people at this conference with a view to involving more members in this work.

\section{Discussion}

In any project, formative evaluation is important to ensure that user needs are being met and that account is being taken of new developments. At the same time, the IASL Web site is essentially the spare-time work of one person, the Webmaster, with some content created by others, including the Review Coordinator, the Editor of School Libraries Worldwide, and the IASL office. This reality governs what is possible, but it also highlights the necessity for ongoing evaluation so that the work that is done is relevant and appropriate.

As indicated earlier in this presentation, the membership of the Association is diverse and encompasses all people who are involved in the provision of school library services at the local and national levels as well as within schools. It also includes educators of school library personnel in universities and colleges as well as students who are studying to become school librarians. It does not include school children. The needs of all these people are monitored and considered in the development of the Web site. In addition, the objectives of the Association provided and continue to provide a framework for development. These factors are important in the organization and development of the Web site as well as in ongoing evaluation. They provide a basis for the selection of materials and services for inclusion in the Web site and for the way in which those resources are organized and indexed. Other factors that have to be taken into account include new developments in school librarianship (which can be identified through the news service on the site as well as through research studies and conference papers) and new developments in Internet technology and browser software. In particular, new software developments sometimes make it possible to offer new services or to do things in a better way.

Ongoing evaluation of "School Libraries Online" is carried out through a number of formal and informal strategies. Some of the monitoring and evaluation strategies are based on the use of technology while others are more traditional. Strategies based on Internet technologies include trackers/counters on the Web site and log files on the mainframe computer on which the site is based. In addition, the "link to" feature of the AltaVista search engine is used to track the number of sites that have linked to "School Libraries Online" as an indicator of popularity with other site developers. Strategies based on more traditional methods include, for example, keeping a record of responses to the Web site (both favorable and unfavorable) and submitting the site for formal evaluation by services such as Encyclopaedia Britannica and The Scout Report. There are plans to survey users of the Web site through a Web-based form. Non-users of the site present a greater challenge, especially since it is known that some non-users do have Internet access.

"School Libraries Online" has changed and developed a great deal since it was established five years ago, and changes are likely to continue. Not only do needs change with time, but new developments in technology enable the Webmaster to meet more needs. Another consideration is that any Web site that remains static will soon find that users move elsewhere. Consequently, at any one time there are usually several new features under consideration or under development for the Web site. 
And now, over to you, the users. What would you like to see on "School Libraries Online"? How would you like to see the site developed? What potential sources of content would you like us to tap into? What contribution could you make to the Web site?

\section{References/Bibliography}

Black, R., \& Elder S. (1997). Web Sites That Work. San Jose: Adobe Press.

Cano, V. \& Prentice, R. (1998). WWW homepages for the tourism industry: The Scottish experience. ASLIB Proceedings, 50(3), 61-68.

Clausen, H. (1999). Evaluation of library Web sites: The Danish case. The Electronic Library, 17(2), 8387.

Clyde, L.A. (1996). The library as information provider: The home page. The Electronic Library, 14(6), 549-558.

Clyde, L.A. (1998). International Association of School Librarianship Website. School Libraries in Canada, 18(1), 7-8.

Clyde, L.A. (1998a). Evaluating and selecting Internet resources. Emergency Librarian, 25(4), 32-35.

Clyde, L.A. (1998b). Weaving an international web. Orana, November, pp.11-17.

Clyde, L.A. (1999). The school library Web site: On the information highway or stalled in the carpark? In L. Lighthall \& E. Howe (Eds.), Unleash the Power! Knowledge, technology, Diversity: Papers Presented at the Third International Forum on Research in School Librarianship, 28th Annual Conference of the International Association of School Librarianship, Birmingham, Alabama, USA, November 10-14, 1999 (pp.227-237). Seattle: International Association of School Librarianship.

Clyde, L.A. (2000). Anne Clyde, IASL Webmaster: A day in her life. School Libraries Worldwide, 6(1), $27-31$.

Dempsey, L. (2000). The subject gateway: Experiences and issues based on the emergence of the Resource Discovery Network", Online Information Review, 24(1), 8-23.

Holzschlag, M. (1998). Web by design: The complete guide. Almeda, California: Sybex.

Koch, T. (2000). Quality-controlled subject gateways: Definitions, typologies, empirical overview. Online Information Review, 24(1), 24-34.

Oberg, D. (2000). International School Library Day: Messages from around the world", School Libraries Worldwide, 6(1), 37-52.

Rosenfeld, L. \& Morville, P. (1998). Information architecture for the World Wide Web. Cambridge: O'Reilly.

Siegel, D. (1997). Secrets of successful web sites. Indianapolis: Hayden Books. 